\title{
Selective and Sensitive Quantification of Acetochlor and S-Metolachlor in Maize and Soybean Plant Samples by Gas Chromatography-Tandem Mass Spectrometry
}

\author{
Irina Gabriela Cara ${ }^{1, *,+}$, Denis Topa ${ }^{2, *,+}$, Lucian Raus ${ }^{2, *}$, Anca Elena Calistru ${ }^{2}$, Feodor Filipov ${ }^{2}$ \\ and Gerard Jitareanu ${ }^{2}$
}

Citation: Cara, I.G.; Topa, D.; Raus, L.; Calistru, A.E.; Filipov, F.; Jitareanu, G. Selective and Sensitive

Quantification of Acetochlor and S-Metolachlor in Maize and Soybean Plant Samples by Gas

Chromatography-Tandem Mass Spectrometry. Agriculture 2021, 11, 283. https://doi.org/10.3390/ agriculture11040283

Academic Editors: Gianluca Caruso, László Baranyai and Vasile Stoleru

Received: 10 March 2021

Accepted: 22 March 2021

Published: 25 March 2021

Publisher's Note: MDPI stays neutral with regard to jurisdictional claims in published maps and institutional affiliations.

Copyright: (c) 2021 by the authors. Licensee MDPI, Basel, Switzerland. This article is an open access article distributed under the terms and conditions of the Creative Commons Attribution (CC BY) license (https:/ / creativecommons.org/licenses/by/ $4.0 /)$.
1 Research Institute for Agriculture and Environment, "Ion Ionescu de la Brad" University of Agricultural Sciences and Veterinary Medicine, 700490 Iasi, Romania

2 Department of Pedotechnics, Faculty of Agriculture, "Ion Ionescu de la Brad" University of Agricultural Sciences and Veterinary Medicine, 700490 Iasi, Romania; aecalistru@uaiasi.ro (A.E.C.); ffilipov@uaiasi.ro (F.F.); gerardj@uaiasi.ro (G.J.)

* Correspondence: carairina@uaiasi.ro (I.G.C.); topadennis@uaiasi.ro (D.T.); rauslucian@uaiasi.ro (L.R.)

$\dagger$ These authors contributed equally to this paper.

\begin{abstract}
Herbicide residue analysis has gained importance worldwide, mainly for food quality control to minimize potentially adverse impacts on human health. A Gas chromatography-tandem mass spectrometry (GC-MS) method for quantitative analysis of acetochlor and s-metolachlor in maize and soybean straw has been developed, validated and applied to analyze the residues of anilide herbicides. Straw material was dried, homogenized and extracted with a mixture of $n$ hexane and acetone by an accelerated solvent extraction method. Chromatographic separation of the target analytes was performed on an Agilent 7832 GC equipped with a mass spectrometer detector, a split-splitless injector and an HP-5 MS (5\% phenylmethyl siloxane) capillary column $(30 \mathrm{~m} \times 0.25 \mathrm{~mm} \times 0.25 \mu \mathrm{m})$. Under these parameters, the limit of detection (LOD) values were $0.2 \mathrm{ng} \mathrm{g}^{-1}$ for acetochlor and $0.07 \mathrm{ng} \mathrm{g}^{-1}$ for s-metolachlor, with average recoveries between $86 \%$ and $119.7 \%$. The method was validated for acetochlor and s-metolachlor in maize and soybean straw at 0.5 and $0.01 \mathrm{mg} \mathrm{kg}^{-1}$. Furthermore, the final residues of the two herbicides in maize and soybean straw were below the maximum residue limit (MRL) at harvest time. The proposed method is suitable for routine analysis.
\end{abstract}

Keywords: acetochlor; s-metolachlor; residues; plant samples; GC-MS

\section{Introduction}

Maize (Zea Mays L.) and soybean (Glycine hispida L.) crops are valuable resources that meet the requirements for human consumption and animal feed as well as for energy production [1]. To obtain the expected yield, the losses related to pests, insects and disease are managed using chemicals pesticides, which inevitably leads to residues in the environment [2]. Acetochlor and s-metolachlor are highly efficient and long-lasting pre-emergent herbicides applied to maize or soybean crops to control a wide range of annual grasses and broadleaf weeds $[3,4]$. Both are systemic herbicides absorbed mainly by shoots and roots of germinating weeds and then translocated to the foliage. The mode of action of these herbicides is via inhibition of cell division and elongation in plants due to the interference with a number of enzymes [4]. Because of their strong herbicidal activities, there are already 654 types of commercially available acetochlor products and approximately $4.2 \%$ of the global s-metolachlor herbicide usage is in Europe $[5,6]$. The long-term and extensive applications of these herbicide (controlled by temperature, soil properties and application history) has resulted in nonpoint source pollution, linked with half-lives ranging between 3 and 9 weeks for acetochlor [7] and 5 and 19 weeks for s-metolachlor [8]. Due to its high water solubility (233 $\mathrm{mg} \mathrm{L}^{-1}$ for acetochlor and 
$530 \mathrm{mg} \mathrm{L}^{-1}$ for s-metolachlor) and moderate to long persistence in soil and water bodies, these active compounds are ones of the most frequently found herbicides in European freshwaters [9-12]. Furthermore, acetochlor and s-metolachlor are endocrine-disrupting chemicals and potential human carcinogens, which can induce endocrine disruption, oxidative stress, and immune-toxicity in nontarget organisms [13].

Towards food safety, the European Union (EU) has established maximum residue limits (MRLs) for acetochlor and s-metolachlor in different products, varying from 0.02 to $0.05 \mathrm{mg} \mathrm{kg}^{-1}[12,14]$. Considering the complexity of plant matrices, a sensitive, rapid and reliable sample preparation method is required, which should accelerate extraction, enhance enrichment of the target compound and minimize interference as much as possible. Analytical methods for acetochlor and s-metolachlor quantification require their analysis by efficient analytical instruments such us tandem mass spectrometry (MS) associated with gas chromatography (GC) [15] or liquid chromatography (LC) [16,17]. Owing to low concentrations of analytes in samples, and the complexity of matrices of real samples, an efficient sample preparation and enrichment process is necessary [15,18].

Common sample processing methods for detecting herbicide residues in different products currently include ultrasound-assisted extraction [19], accelerated solvent extraction [17], ultrasonic solvent extraction or pressurized liquid extraction [18], as well as microwave-assisted [20] and hollow fiber-liquid phase microextraction [21]. However, all these methods usually have required sample manipulation to minimize sample contamination and achieve the desired sensitivity and selectivity.

Accelerated solvent extraction is a reliable extraction technique where different conditions are used to increase the extraction performance. Various parameters and extraction conditions (high temperature and/or pressure) increase the solvent solubilizing capacity and penetration power to enter into sample matrix and increase the contact time for solvent and sample [17]. In addition, the cycle time of Accelerated Solvent extraction (ASE) ensures the possibility of equilibrium time for intra- and extracellular solutions. The end result is a smaller solvent quantity with more contact time and more effective solubilization in a short period of time under high pressure. As it has different advantages, ASE offers the versatility of extracting a wide range of compounds from different chemical families [22]. Integrated ASE/GC-MS has been successfully used for the analysis of various pesticide residues in food, soil, sediments and water [23]. ASE/GC-MS, characterized by its low solvent consumption, shorter extraction time and high analyte recovery, has been recommended as the standard USEPA Method SW-8463545A [21].

The continued increased global inquiry has raised concerns about agricultural products safety because pesticide residues in maize, soybean and other cereals could present a significant risk to human health $[1,14]$. Maximum Residues Limits (MRLs) are typically enforced at European Union or international levels to avoid health hazards and excessive exposure [11]. In the conditions where MRLs are exceeded, the consumers can be at risk. Currently, health risk assessment of human pesticide exposure through dietary intake is widely used as a valuable tool for food quality and safety monitoring [11,16].

With this background, the aim of this work is to develop and validate an analytical method for quantitative analysis of acetochlor and s-metolachlor in soybean and maize plants. The method presents a short analytical run time and produces accurate and repeatable results as confirmed through validation. Moreover, the developed method was applied to real samples collected from Experimental Farm of Agriculture University, Romania, in order to monitor the environmental state in these regions.

\section{Materials and Methods}

\subsection{Chemicals and Materials}

Acetochlor (95\% purity) and s-metolachlor (97\% purity) reference standard was provided by Dr. Ehrenstorfer Chemical Industries (Augsburg, Germany). Their molecular structures are shown in Figure 1. Chromatography grade acetone, n-hexane and dichloromethane were purchased from Merck, Germany. Stock solution of the individ- 
ual standards $\left(1000 \mathrm{mg} \mathrm{L}^{-1}\right)$ were dissolved in acetone and stored at $4{ }^{\circ} \mathrm{C}$. Working standard solutions were prepared by diluting the stock solution with n-hexane to the required concentrations.<smiles>CCOCN(C(=O)CCl)c1c(C)cccc1CC</smiles>

(a)<smiles>CCc1cccc(C)c1N(C(=O)CCl)[C@@H](C)COC</smiles>

(b)

Figure 1. Molecular structures of acetochlor (a) and s-metolachlor (b).

\subsection{Instrumental}

GC-MS analysis was carried out using an Agilent 7832 GC instrument equipped with an Agilent 5977B mass spectrometer detector (Agilent Technologies, Santa Clara, CA, USA) in electron ionization and scan modes. Chromatographic separation was performed using a HP-5MS (5\% phenylmethyl siloxane) capillary column $(30 \mathrm{~m} \times 0.25 \mathrm{~mm} \times 0.25 \mu \mathrm{m})$. The GC oven temperature was programed as follows: $50{ }^{\circ} \mathrm{C}(1 \mathrm{~min}), 50-200{ }^{\circ} \mathrm{C}$ at $30{ }^{\circ} \mathrm{C}$ $\min ^{-1}, 200-280{ }^{\circ} \mathrm{C}$ at $10{ }^{\circ} \mathrm{C} \min ^{-1},(1 \mathrm{~min}), 280-310^{\circ} \mathrm{C}$ and finally held for $3 \mathrm{~min}[20,22]$. A constant flow rate of the helium carrier gas was $0.8 \mathrm{~mL} \mathrm{~min}^{-1}$. The injection was performed in splitless mode with an injection volume of $1 \mu \mathrm{L}$ and a temperature of $250^{\circ} \mathrm{C}$. The mass spectrometer detector was operated in scan mode and the temperatures of the transfer line and the ion source were set at 300 and $280{ }^{\circ} \mathrm{C}$, respectively [23]. The MS parameters and representative chromatograms of acetochlor and s-metolachlor are shown in Table 1 and Figure 2.

Table 1. Gas chromatography-tandem mass spectrometry (GC-MS) parameters of acetochlor and s-metolachlor.

\begin{tabular}{cccc}
\hline Analyte & Retention Time & $\begin{array}{c}\text { Qualifying Ions } \\
(\mathbf{m} / \mathbf{z})\end{array}$ & $\begin{array}{c}\text { Quantifying Ions } \\
(\mathbf{m} / \mathbf{z})\end{array}$ \\
\hline Acetochlor & 8.10 & $162.0,146.0,174.0$ & 146.0 \\
\hline s-metolachlor & 8.78 & $162.0,238.0,211.0$ & 162.0 \\
\hline
\end{tabular}
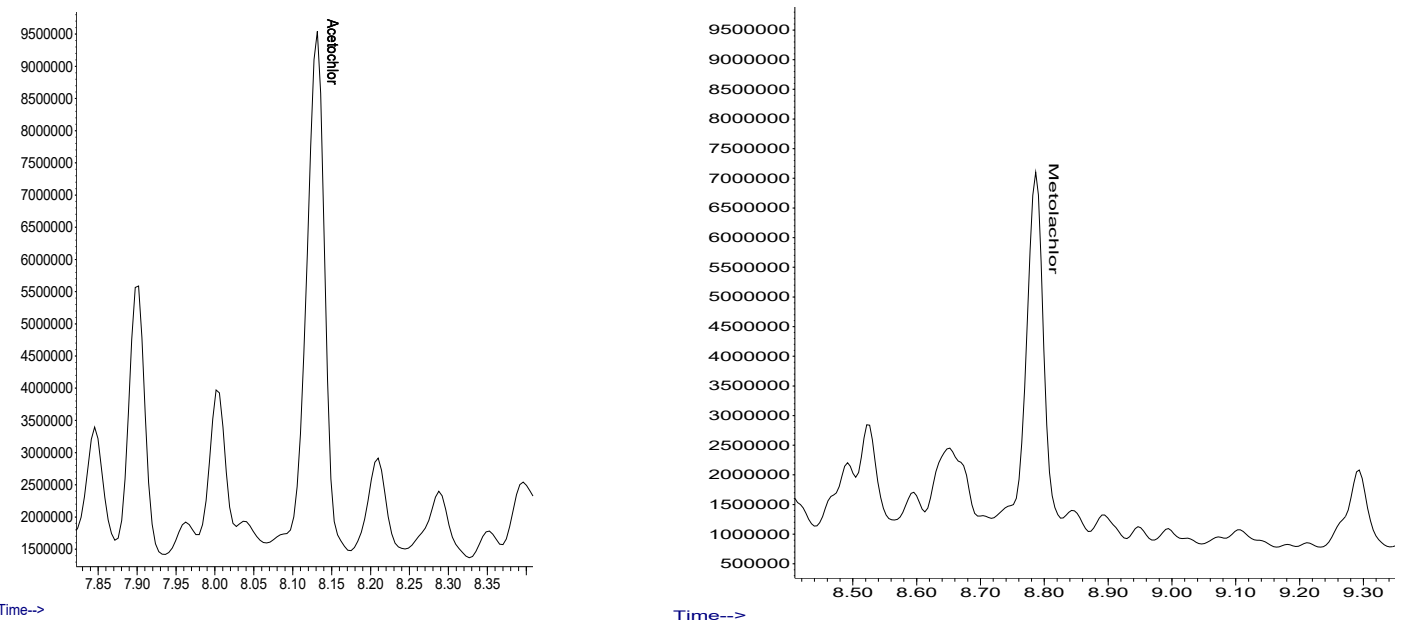

Figure 2. The GC-MS chromatograms of acetochlor and s-metolachlor in scan mode. 


\subsection{Sample Collection and Preparation}

Maize (variety DKC 4943) and soybean straw plants (Condor C1) were obtained from the Research Farm of the Agricultural University Iasi-Romania $\left(47^{\circ} 07^{\prime} \mathrm{N}\right.$ latitude, $27^{\circ} 30^{\prime} \mathrm{E}$ longitude). One treatment with Guardian (820-860 $\mathrm{g} \mathrm{L}^{-1}$ a.i. acetochlor) and Dual Gold (86.5\% a.i. s-metolachlor) was conducted in a plot with an area of $126 \mathrm{~m}^{2}$. The control (blank sprayed with clear water) was performed synchronously with a surface area of $126 \mathrm{~m}^{2}$. The good agricultural practice details given by the manufacturer was as follows: recommended dosages were $2.5 \mathrm{~L} \mathrm{ha}^{-1}$ for Guardian and $1.5 \mathrm{~L} \mathrm{ha}^{-1}$ for Dual Gold, while the application method was before and after sowing.

The straw samples (at least 50 for each plant sample) were collected at crop harvest time. After collection, the straw samples were washed, air dried and passed through a $2 \mathrm{~mm}$ sieve and stored in sterile glass bottles in the dark at $4{ }^{\circ} \mathrm{C}$ until analysis.

\subsection{Accelerated Solvent Extraction Procedure}

A Dionex Accelerated Solvent Extraction system (ASE-300, Thermo Scientific, Waltham, MA, USA) was used to extract acetochlor and s-metolachlor from straw samples. Cellulose extraction filters were placed on the bottom of the stainless-steel extraction cells $(35 \mathrm{~mL})$ to avoid the fine particles from going into the collection bottle and ensure consistent extraction volumes. Then, $10 \mathrm{~g}$ of maize and soybean straw plants was mixed with $3 \mathrm{~g}$ Diatomaceous earth and the mixture was added in the ASE cells.

The ASE system was operated under the following conditions: 1500 psi pressure, 80-150 ${ }^{\circ} \mathrm{C}$ temperature, $3-5$ min heat-up time, $40-70 \%$ flush volume, and $2-5$ extraction cycles. Several solvents were tested, including acetone, n-hexane, dichlormethane and $\mathrm{n}$-hexane and acetone $(1: 1 \mathrm{v} / \mathrm{v})$ mixture. After static extraction, the extraction cell was purged with nitrogen for $1 \mathrm{~min}$ [24]. The extracts were collected in $240 \mathrm{~mL}$ collection bottles and concentrated to about $5 \mathrm{~mL}$ with a rotary evaporator, then evaporated at $50{ }^{\circ} \mathrm{C}$ to dry. The residue was then reconstituted to $1 \mathrm{~mL}$ with dichlormethane for subsequent clean-up.

\subsection{Method Validation}

The validation of the developed method was carried out according to the European guideline SANTE/12682/2019 with the following analytical parameters: selectivity, accuracy, linearity, precision and trueness, matrix effect, limit of detection (LOD), limit of quantification (LOQ). At five concentration levels ranging from 0.001 to $0.05 \mathrm{mg} \mathrm{L}^{-1}$, solvent and matrix effect standard calibration curves were built and injected into the GC-MS system. The linearity study was calculated by the correlation coefficient $\left(R^{2}\right)$ of the matrix matched calibration curves. The slope ratio between the calibration curves obtained in matrix and in solvent was tested for matrix effects. Recovery tests were carried out for each matrix at two spiked concentrations $\left(0.05\right.$ and $\left.0.1 \mathrm{mg} \mathrm{kg}^{-1}\right)$ with five replicates at each stage to test the accuracy of the method. By using the relative standard deviation (RSD), the precision in terms of repeatability intraday and interday were evaluated. Spiked samples at two concentrations with five replications were injected in the same day to assess the intraday precision and the RSD was measured. The interday precision was assessed on two different days with five replications and calculation of the RSD. The limit of detection (LOD) of the proposed method was estimated on a signal-to noise ratios $(\mathrm{S} / \mathrm{N})$ of 3 . The limit of quantification (LOQ) was defined as the lowest spiked level of the validation meeting the method performance acceptability criteria.

\section{Results}

3.1. Optimization of the ASE Procedure

3.1.1. Solvent Selection

Drying and homogenization followed by accelerate solvent extraction using a low polarity solvent has proven to be an efficient, reproducible and simple extractive method for acetochlor and s-metolachlor. Various solvents such as pure n-hexane, acetonitrile and a mixture of acetone and DCM, DCM and ethylacetate have been used for the ASE of anilide 
herbicides $[17,24,25]$. The best extraction efficiency requires selection of an appropriate solvent which has similar polarity with target analytes [26,27]. The proper solvents should have high solubility towards the target compounds, selective towards coextractors and cause little or no interference with the determination [20]. Dichlormethane failed to be considered as an effective extraction solvent as it had the lowest recoveries (37-42\%) compared to the other three solvents combinations. The pure solvents acetone and nhexane exhibited smaller recoveries (79-87\%) of acetochlor and s-metolachlor compared to solvent mixtures whose recovery values were increased. Acetochlor and s-metolachlor are low polarity compounds with octanol-water partition coefficients, $\mathrm{K}_{\mathrm{OW}}$, between 3.05 and $4.14[5,9]$. Considering the physical-chemical properties of the herbicides, the appropriate solvent that exhibited a high recovery $(114 \%)$ was a mixture of n-hexane and acetone $(1: 1 \mathrm{v} / \mathrm{v})$ (Figure 3). The n-hexane and acetone mixture is a kind of low polar solvent which dissolved the target compounds better than other solvents. Figure 3 shows that the highest extraction efficiency (recovery from $37 \%$ to $114 \%$ ) for the two active ingredients was obtained when n-hexane and acetone were used as extraction solvents.

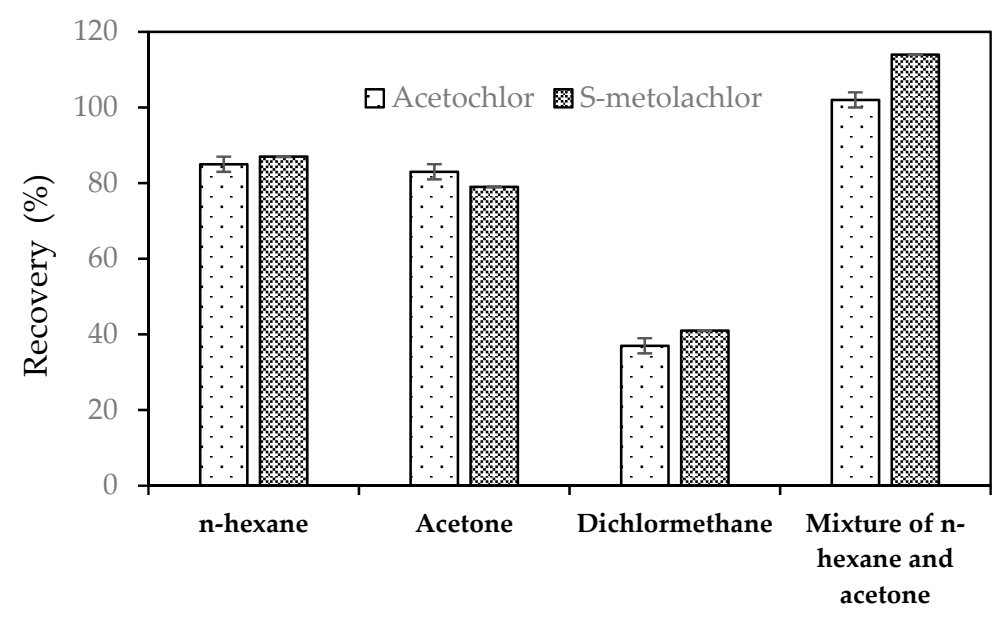

Figure 3. Influence of solvent type on the acetochlor and s-metolachlor extraction procedure.

\subsubsection{Effect of Temperature}

It is known that increasing temperature improves the penetrability and solubility of the solvent, thus enhancing extraction efficiencies. Increased extraction efficiency is linked with reduction in solvent viscosity and surface tension, which enhance exposure of analytes to solvent [26,27]. Different temperatures affect the ASE procedure by improving the extraction of acetochlor and s-metolachlor when the temperature increases from 80 to $140{ }^{\circ} \mathrm{C}$ (Figure 4) [28]. At high temperatures $\left(160^{\circ} \mathrm{C}\right)$, the stability of acetochlor and s-metolachlor decreases while the coextractors start to increase [23]. The highest recovery values were obtained at $140{ }^{\circ} \mathrm{C}-97 \%$ for s-metolachlor and $105 \%$ for acetochlor.

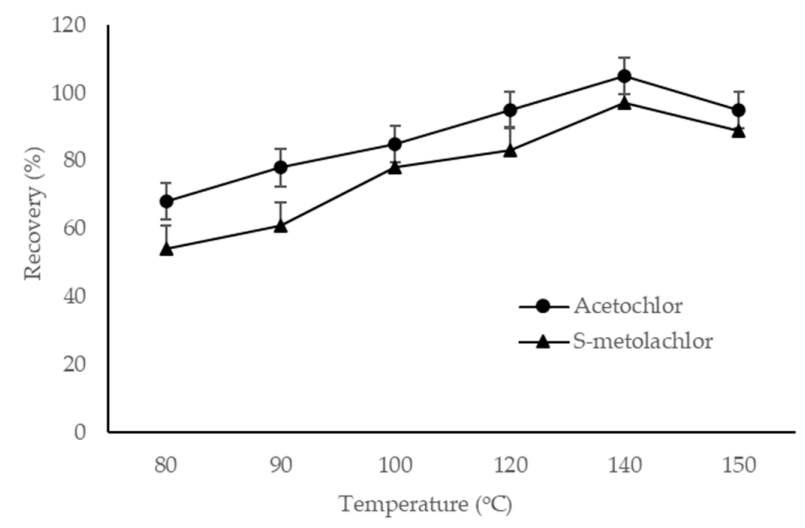

Figure 4. The influence of extraction temperature. 


\subsubsection{Effect of Exposure and Number of Extraction Cycles}

In order to diffuse the target compound into the extraction solvent, the static extraction time can be increased. However, our results showed that the static time increased from 3 to $5 \mathrm{~min}$ and one cycle gave the maximum extraction efficiency. Data indicate that the recoveries were lower after two extraction cycles. The recoveries of acetochlor and s-metolachlor in the second cycle were $1.3 \%$ and $1.05 \%$ and those in the third cycle were below the limits of detection. Therefore, the optimal number of extraction cycles was one in order to save solvent and time and increase analytical time. To provide the quantities of acetochlor and s-metolachlor elutes, the rinse volume was also optimized and it was associated with the final volume. Different flushing solvent volumes $(40 \%, 50 \%, 60 \%$ and $70 \%$ ) were investigated, and the $60 \%$ cell volume was enough to eluate the analytes from the extraction cell.

\subsection{Method Validation}

Good regression equations and correlation coefficients $\left(R^{2}\right)$ were achieved for both tested herbicides (Tables 2 and 3). The linear concentrations of an individual pesticide, such as $0.001,0.005,0.01$ and $0.05 \mathrm{mg} \mathrm{L}^{-1}$, established a linear correspondence among detector response and herbicide concentrations. The selected chromatographic parameters for acetochlor and s-metolachlor have obtained the correlation coefficients $\left(R^{2}\right)$ in the range of 0.991 to 0.998 .

Table 2. Analytical characteristics of the optimized Accelerated Solvent extraction (ASE)/GC-MS method for the two herbicides.

\begin{tabular}{cccccc}
\hline Analyte & $\begin{array}{c}\text { Correlation } \\
\text { Coefficient } \mathbf{( R}^{\mathbf{2}} \mathbf{)}\end{array}$ & $\begin{array}{c}\text { Linear Range } \\
\left(\mathbf{m g ~ L}^{-\mathbf{1}}\right)\end{array}$ & $\begin{array}{c}\text { LOD } \\
\left(\mathbf{n g ~ g}^{-\mathbf{1}}\right)\end{array}$ & $\begin{array}{c}\text { LOQ } \\
\left(\mathbf{n g ~ g}^{-\mathbf{1}}\right)\end{array}$ & $\begin{array}{c}\mathbf{R S D} \\
\mathbf{( \% )}\end{array}$ \\
\hline $\begin{array}{c}\text { Acetochlor } \\
\text { s-metolachlor }\end{array}$ & 0.993 & $0.001-0.05$ & 0.2 & 0.67 & 1.7 \\
\hline
\end{tabular}

LOD—limit of detection, LOQ—-limit of quantification, RSD—relative standar deviation.

Table 3. The mean recovery, matrix effect (Me) and relative standard deviations (RSDs) of acetochlor and s-metolachlor.

\begin{tabular}{|c|c|c|c|c|c|c|c|}
\hline \multirow{2}{*}{ Analyte } & \multirow{2}{*}{$\begin{array}{c}\text { Straw } \\
\text { Sample } \\
n=5\end{array}$} & \multirow{2}{*}{$\mathbf{R}^{2}$} & \multirow{2}{*}{ Me } & \multicolumn{2}{|c|}{$\begin{array}{c}\text { Mean Recovery } \\
(\%)\end{array}$} & \multirow[t]{2}{*}{$\begin{array}{l}\text { Intraday } \\
\text { RSD (\%) }\end{array}$} & \multirow{2}{*}{$\begin{array}{l}\text { Interday } \\
\text { RSD (\%) }\end{array}$} \\
\hline & & & & $\begin{array}{c}0.05 \mathrm{mg} \\
\mathrm{kg}^{-1}\end{array}$ & $\begin{array}{c}0.1 \mathrm{mg} \\
\mathrm{kg}^{-1}\end{array}$ & & \\
\hline Acetochlor & Maize & 0.996 & 0.87 & 85.5 & 104.7 & $1.2-3.4$ & 2.6 \\
\hline s-metolachlor & Soybean & 0.998 & 0.92 & 83.4 & 112.9 & $2.4-4.8$ & 1.5 \\
\hline
\end{tabular}

The LODs were ranged between 0.07 and $0.2 \mathrm{ng} / \mathrm{g}$ [29]. The LOQ for acetochlor and s-metolachlor was 0.19 to $0.67 \mathrm{ng}$ g based on a good recovery within the range $95-102 \%$. The obtained LOD and LOQ values highlight the sensitivity of the method, as the pesticide could be analyzed below the MRLs set by the EU $\left(0.01 \mathrm{mg} \mathrm{kg}^{-1}\right)$.

Maize and soybean straw were spiked at 0.1 and $0.05 \mathrm{mg} \mathrm{kg}^{-1}$ level using individual working standard and registered 83.4 to $119.3 \%$ and 85.5 to $112.7 \%$ of the recoveries, with RSD less than $20 \%$ at all spiked levels (Table 3 and Figure 5). The accuracy of the method was assessed for each herbicide by comparing the measured true values with spiked values, which is acceptable based on the SANTE guideline. 


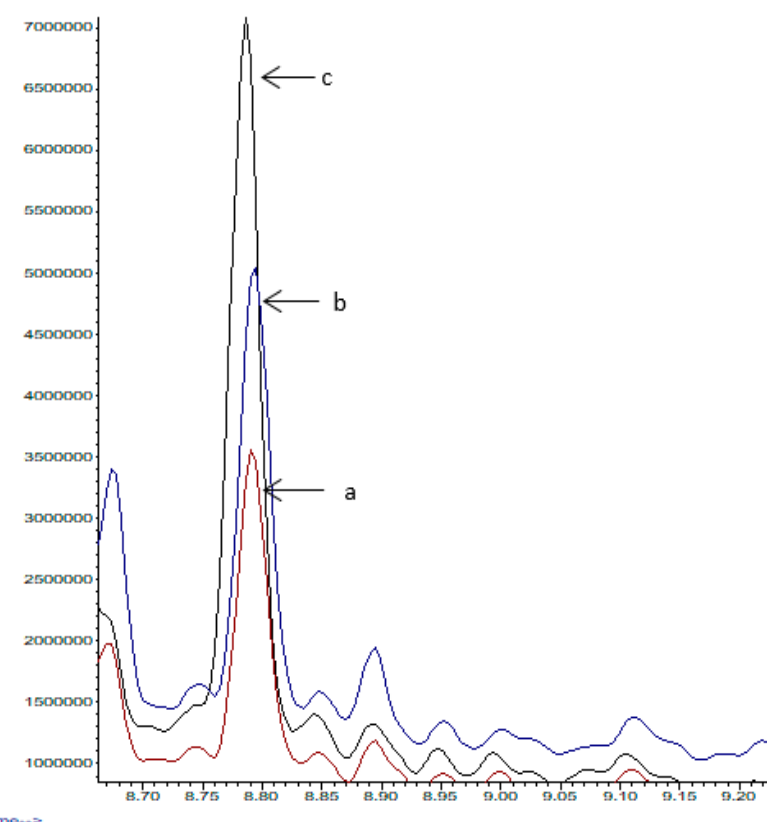

Figure 5. Chromatogram of s-metolachlor in soybean straw samples (a) and spiked soybean straw samples at 0.05 (b) and $0.1 \mathrm{mg} \mathrm{kg}^{-1}$ (c).

The recovery range of $81.20 \%$ to $112.9 \%$ was shown by repeatability estimation with relative standard deviation in the range of $3.2 \%$ to $6.8 \%$. Under optimal conditions, the precision with intra- and interday tests registered recoveries of $82.3 \%$ to $105.3 \%$ and $83.6 \%$ to $104.8 \%$, with the RSD in the range of $1.2 \%$ to $4.8 \%$, respectively. The system validation results in maize and soybean straw showed that the modified accelerate solvent extraction with GC-MS detection was accurate and sensitive when detecting the two herbicides that are members of anilide family.

\subsection{Application to Real Samples}

The developed GC-MS method was applied through the quantitation of acetochlor and s-metolachlor of 50 maize and soybean straw samples after application in an experimental field. Under optimized conditions, a straw chromatogram of the real and spiked samples was obtained (Figure 5). Each analyte had the same retention time as the standard compound in straw samples and spiked straw samples, respectively. At the retention time of acetochlor and s-metolachlor, no interference peaks were observed. Acetochlor was detected at concentrations at or above the LOQ in $85 \%$ of the samples with mean levels of $0.73 \mathrm{ng} \mathrm{g}^{-1}$ and maximum concentration of $0.97 \mathrm{ng} \mathrm{g}^{-1}$ For s-metolachlor $73 \%$ of the samples were over the LOQ, with a mean level of $0.21 \mathrm{ng} \mathrm{g}^{-1}$ and a maximum of $1.4 \mathrm{ng}$ $\mathrm{g}^{-1}$. The current approach yields good recoveries in the range of $81.9 \%-103.1 \%$ as well as adequate precision with an RSD less than $5 \%$. Owing to the enhanced sensitivity, the scale of quantifiable data increased, obtaining more environmental knowledge regarding acetochlor and s-metolachlor.

\section{Discussion}

In this study, acetochlor and s-metolachlor identification and quantification were based on GC-MS according to their retention times using scan mode. Therefore, distinct conditions were optimized to achieve an admissible resolution between the components and a reasonable run time with agreeable recoveries that meet the suitability requirements $[27,28]$. Good separation was obtained under the optimized chromatographic conditions and the retention times of acetochlor and s-metolachlor were 8.11 and $8.78 \mathrm{~min}$, respectively.

The combined ASE/GC-MS method was successfully used for the analysis of acetochlor and s-metolachlor, exhibiting good linearity, reproducibility and recovery. 
Optimization of the ASE parameters, for prudent selection of solvents, temperature, static period and static cycles, can influence the extraction procedure [29]. Since extraction solvent temperature, static extraction time and cycle were among the favorable ranges, the extraction process was achieved with a frequently used low polar solvent mixture. The highest chromatographic peak areas for the tested acetochlor and s-metolachlor compounds were obtained using $\mathrm{n}$-hexane and acetone. Based on the relative polarities of the solvents and taking into account that the anilide herbicides are low polar compounds, the best extraction was expected with low polar solvents [30,31].

It is generally known that increasing temperature affect extraction kinetics. To obtain an efficient extraction on accelerate solvent extraction, slight modification of the temperature was carried out [32]. To ensure the stability of acetochlor and s-metolachlor, the extraction temperature was set to $140^{\circ} \mathrm{C}$.

In an accelerated solvent extraction procedure, the static extraction time and cycles are additional elementary experimental parameters. Extraction times establish an equilibrium beyond which an increase in time should not have consequence on extraction performance. However, our results reveal that solvents with extraction times longer than $5 \mathrm{~min}$ offer reduced recoveries with increasing volumes of the extraction solution and extend the extraction time $[23,27,30]$. The highest recovery values, $95.6 \%$ and $102.2 \%$ for acetochlor and s-metolachlor, were obtained within $5 \mathrm{~min}$. The number of extraction cycles based on average recoveries indicate that only one cycle operation was efficient in terms of saving solvent and increasing analytical rate.

The suggested ASE sample processing coupled with a GC-MS approach was compared to other chromatographic analysis techniques from the literature used to determine acetochlor and s-metolachlor $[33,34]$. Certainly, the proposed approach has a larger linear range and lower LOD and RSD than the other methods, which makes it significantly better. Additionally, the advantages of this technique include simplicity of use, maximum efficiency, low solvent consumption, and environmental conservation. Furthermore, this method has significant labor-saving and budget benefits. Overall, this approach is highly selective, sensitive, and precise, and it has the potential to be used in everyday research.

Real samples collected from the Research Farm of the Agricultural University IasiRomania were extracted according to the ASE procedure established. The obtained results show that the concentration of acetochlor and s-metolachlor were under limitation values [14]. Major breakdown processes under natural conditions depend on physicalchemical properties of the herbicides and soil $\mathrm{pH}$ and properties, moisture and microorganisms. The maize and soybean crops were grown in Romania under temperate conditions, and the straws were allowed to dry in the field after reaching maturity, which may be the reason for low residues $[4,35]$. The concentrations of anilide herbicides in plant samples were comparable to those of other field studies $[20,28]$. In a comparable study on acetochlor residues, no residues were quantified in real samples using HPLC-MS/MS and GC-MS. This type of herbicide belongs to the category of low residue pesticides and, taking into account other factors such as soil $\mathrm{pH}$ and properties as well as environmental conditions, almost $90 \%$ of the residues were degraded.

\section{Conclusions}

In this study, a simple and efficient method for the extraction and quantitation of acetochlor and s-metolachlor in maize and soybean plants was reported. The optimized ASE procedure ensures less solvent consumption and lower sample preparation time with reduced operational labor. The suggested method introduces varied benefits in terms of sensitivity, accuracy and selectivity, and it is possible that it can be used in other matrices.

Author Contributions: I.G.C. and D.T. were involved in writing and laboratory analysis; L.R. and G.J. analyzed the data and performed research supervision; A.E.C. and F.F. collected the samples; I.G.C., D.T., and L.R. planned the protocol, material analysis tools and prepared the manuscript. All authors have read and agreed to the published version of the manuscript. 
Funding: This work was financially supported by Competitiveness Operational Programme (COP) 2014-2020. The funders were not involved in the study's design.

Institutional Review Board Statement: Not applicable.

Informed Consent Statement: Not applicable.

Data Availability Statement: Not applicable.

Acknowledgments: Authors acknowledge the logistic support from the Competitiveness Operational Programme (COP) 2014-2020, under the project number 4/AXA1/1.2.3. G/05.06.2018, SMIS2014+ code 119611, with the title "Establishing and implementing knowledge transfer partnerships between the Institute of Research for Agriculture and Environmen-IASI and agricultural economic environment".

Conflicts of Interest: The authors declare no conflict of interest.

\section{References}

1. Roman, K.; Barwicki, J.; Hryniewicz, M.; Szadkowska, D.; Szadkowski, J. Production of Electricity and Heat from Biomass Waste using a Converted Aircraft Turbine AI-20. Processes 2021, 9, 364. [CrossRef]

2. Harischandra, N.R.; Pallavi, M.S.; Bheemanna, M.; PavanKumar, K.; Reddy, V.C.S.; Udaykumar, N.R.; Paramasivam, M.; Yadav, S. Simultaneous determination of 79 pesticides in pigeonpea grains using GC-MS/MS and LC-MS/MS. Food Chem. $2021,347$. [CrossRef]

3. Ju, C.; Zhang, H.; Wu, R.; Dong, S.; Yao, S.; Wang, F.; Cao, D.; Xu, S.; Fang, H.; Yu, Y. Upward translocation of acetochlor and atrazine in wheat plants depends on their distribution in roots. Sci. Total Environ. 2020, 703. [CrossRef]

4. Yu, Q.; Zhang, P.; He, Y.; Xu, Z.; He, X.; Hu, Y.; Zhang, H.; He, L. Dissipation Dynamics and Residue of Four Herbicides in Paddy Fields using HPLC-MS/MS and GC-MS. Int. J. Environ. Res. Public Health 2019, 16, 236. [CrossRef]

5. Pannacci, E.; Del Buono, D.; Bartucca, M.L.; Nasini, L.; Proietti, P.; Tei, F. Herbicide uptake and regrowth ability of Tall Fescue and Orchardgrass in s-metolachlor-contaminated leachates from sand pot experiment. Agriculture 2020, 10, 487. [CrossRef]

6. Chang, X.; Liang, J.; Sun, Y.; Zhao, L.; Zhou, B.; Li, X.; Li, Y. Isolation, degradation performance and field application of the metolachlor-degrading fungus Penicillium oxalicum MET-F-1. Appl. Sci. 2020, 10, 8556. [CrossRef]

7. PPDB (Pesticide Properties Data Base). Acetochlor, General Information. University of Hertfordshire, UK. 2020. Available online: https://sitem.herts.ac.uk/aeru/ppdb/en/Reports/12.htm (accessed on 15 December 2020).

8. Janniche, G.S.; Mouvet, C.; Albrechtsen, H.J. Acetochlor sorption and degradation in limestone subsurface and aquifers. Pest. Manag. Sci. 2010, 66, 1287-1297. [CrossRef]

9. Wu, X.; Li, M.; Long, Y.; Liu, R.; Yu, Y.; Fang, H.; Li, S. Effects of adsorption on degradation and bioavailability of metolachlor in soil. J. Soil Sci. Plant Nutr. 2011, 11, 83-97.

10. Velisek, J.; Stara, A.; Zuskova, E.; Kubec, J.; Buric, M.; Kouba, A. Effects of s-metolachlor on early life stages of marbled crayfish. Pestic. Biochem. Physiol. 2019, 153, 87-94. [CrossRef]

11. Zemolin, C.R.; Avila, L.; Cassol, G.; Massey, J.H.; Camargo, E. Environmental fate of S-Metolachlor: A review. Planta Daninha 2014, 32, 655-664. [CrossRef]

12. PPDB (Pesticide Properties Data Base). S-metolachlor, General Information. University of Hertfordshire, UK. 2020. Available online: https://sitem.herts.ac.uk/aeru/ppdb/en/Reports/465.htm (accessed on 17 December 2020).

13. Jiang, J.; Wu, S.; Liu, X.; Wang, Y.; An, X.; Cai, L.; Zhao, X. Effect of acetochlor on transcription of genes associated with oxidative stress, apoptosis, immunotoxicity and endocrine disruption in the early life stage of zebrafish. Environ. Toxicol. Pharmacol. 2015, 40, 516-523. [CrossRef] [PubMed]

14. Eu, Pesticide MRL Database. 2020. Available online: https://ec.europa.eu/food/plant/pesticides/max_residue_levels/eu_ rules_en (accessed on 20 January 2021).

15. Wang, D.; Wu, S. Development and validation of a GC-MS method for the simultaneous determination of acetochlor, fluorochloridone and pendimethalin in herbicide emulsifiable concentrate formulation. Acta Chromatograph. 2020, 32, $238-241$. [CrossRef]

16. Ping, H.; Pan, L.G.; Shu, X.L.; Lu, A.X. Multiresidue Determination of Thifensulfuron-Methyl, Atrazine and Acetochlor in Soybeans by High Performance Liquid Chromatography. Sens. Lett. 2011, 9, 1180-1183. [CrossRef]

17. Wu, X.; Shen, S.; Yan, H.; Yuan, Y.; Chen, X. Efficient enrichment and analysis of atrazine and its degradation products in Chinese Yam using accelerated solvent extraction and pipette tip solid-phase extraction followed by UPLC-DAD. Food Chem. 2021, 337. [CrossRef] [PubMed]

18. Lesueur, C.; Gartner, M.; Mentler, A.; Fuerhacker, M. Comparision of four extraction methods for the analysis of 24 pesticides in soil samples with gas chromatography-mass spectrometry and liquid chromatography ion trap mass spectrometry. Talanta 2008, 75, 284-293. [CrossRef] [PubMed]

19. Pensabene, J.W.; Fiddler, W.; Donoghue, D.J. Supercritical fluid extraction of atrazine and other triazine herbicides from fortified and incurred eggs. J. Agric. Food Chem. 2000, 48, 1668-1672. [CrossRef] [PubMed] 
20. Hu, E.; Cheng, H. Rapid extraction and determination of atrazine and its degradation products from microporous mineral sorbents using microwave-assisted solvent extraction followed by ultra-HPLC-MS/MS. Microchim. Acta 2013, 180, 703-710. [CrossRef]

21. Megersa, N. Hollow fiber liquid phase microextraction for race enrichment of the residues of atrazine and its major degradation products from environmental water and human urine samples. Anal. Methods 2015, 7, 9940-9948. [CrossRef]

22. Richter, B.E.; Jones, B.A.; Ezzell, A.J.L.; Porter, N.L.; Avdalovic, N.; Pohl, C. Accelerated Solvent Extraction: A Technique for Sample Preparation. Anal. Chem. 1996, 68, 1033-1039. [CrossRef]

23. Xu, X.Q.; Li, Q.L.; Yuan, J.D.; Wang, S.G.; Wang, W.S.; Lee, F.S.C.; Wang, X.R. Determination of three kinds of chloroacetanilide herbicides in Radix Pseudostellariae by Accelerated Solvent Extraction and Gas chromatography mass spectrometry. Chin. J Anal. Chem. 2007, 35, 206-210. [CrossRef]

24. Zhao, X.; Wang, B.; Xie, K.; Liu, Y.; Zhang, Y.; Liu, C.; Guo, Y.; Bu, X.; Zhang, G.; Zhang, T.; et al. Development of an Ase-Gs-ms/ms method for detecting dinitolmide and its metabolite 3-ANOT in eggs. J. Mass. Spectrom. 2018, 53, 976-985. [CrossRef] [PubMed]

25. Kahn, B.B.; Tomkins, D.F. Determination of acetochlor in technical and formulated products by capillary gas chromatography. Agric. Mat. 2001, 84, 317-322. [CrossRef]

26. Blanchoud, H.; Alliot, F.; Chen, N.; Valdes, D. Rapid SPE-LCMS/MS analysis of atrazine, its by products, simazine and s-metolachlor in groundwater samples. Methodsx 2020, 7. [CrossRef]

27. Bodur, S.; Borahan, T.; Ates, N.; Bakirdere, S. Sensitive determination of acetochlor, metolachlor and fenthion utilizing shaking assisted dispersive liquid-liquid microextraction prior to gas chromatography-mass spectrometry. B Environ. Contam. Toxicol. 2020, 105, 460-467. [CrossRef]

28. Yokley, R.A.; Mayer, L.C.; Huang, S.B.; Vargo, J.D. Analytical method for the determination of metolaclor, acetochlor, alachlor, dimethenamid and their corresponding ethanesulfonic and oxanilic acid degrdates in water using SPE and LC/ESI-MS/MS Anal. Chem. 2002, 74, 3754-3759. [CrossRef]

29. Ning, M.; Jun, Y.; Meseret, A.; Langping, W.; Geoffrey, S.; Li, H.; Chen, Y.; Liu, J.; Mihuez, V.G. Accelerated solvent extraction combined with GC-MS: A convenient technique for the determination and compound specific stable isotope analysis of phthalates in mine tailings. Microchem. J. 2020, 153. [CrossRef]

30. Sun, H.W.; Ge, X.S.; Lv, Y.K.; Wang, A.B. Application of accelerate solvent extraction in the analysis of organic contaminants, bioactive and nutritional compounds in food and feeds. J. Chrom. A 2012, 1237, 1-23. [CrossRef]

31. Zhang, Y.; Yang, J.; Shi, R.; Su, Q.; Yao, L.; Li, P. Determination of acetanilide herbicides in cereal crops using accelerated solvent extraction, solid-phase extraction and gas chromatography-electron capture detector. J. Sep. Sci. 2011, 34, 1675-1682. [CrossRef] [PubMed]

32. Yang, J.; Li, Q.; Wang, L.; Shao, J.; Mei, W.; Wang, L. Development and application of a dispersive solid-phase extraction method for the simultaneous determination of chloroacetamide herbicide residues in soil by gas chromatography-tandem mass spectrometry (GC-MS/MS). Int. J. Environ. Anal. Chem. 2019, 99, 282-296. [CrossRef]

33. Wang, L.; Li, C.; Peng, C.; Li, X.; Xu, C.; Li, C. A rapid multi-residue determination method of herbicides in grain by GC-MS-SIM. J. Chromatogr. Sci. 2008, 46, 424-429. [CrossRef]

34. Xu, X.; Yang, H.; Wang, L.; Han, B.; Wang, X.; Lee, F.S.-C. Analysis of chloroacetanilide herbicides in water samples by solid-phase microextraction coupled with gas chromatography-mass spectrometry. Anal. Chim. Acta 2007, 591, 87-96. [CrossRef] [PubMed]

35. Konieczna, A.; Roman, K.; Roman, M.; Sliwinski, D.; Roman, M. Energy Efficiency of Maize production Technology: Evidence from polish Farms. Energies 2021, 14, 1-20. 